\title{
Management Evaluation of the Healthy Athlete program of 2007 Shanghai Special Olympics World Summer Games 從管理角度探討2007年上海夏季特殊奧運會健康運動員計劃
}

\author{
Michael H. S. LAM \\ Department of Physical Education, \\ Hong Kong Baptist University, HONG KONG \\ 林絢琛 \\ 香港浸會大學體育學系
}

\begin{abstract}
Customer satisfaction which directly affected service quality is very important in organizing events (Lassar, Manolis \& Winsor, 2000). According to the Healthy Athlete Screening Report conducted by the International Special Olympics (2007), there were 7289 athletes registered for the 2007 Shanghai Special Olympics World Summer Games and 4879 (66.9\%) of the total athletes participated the Healthy Athlete screening. Facing large amount of customers, the management evaluation based on customer satisfaction was examined with the Importance-Performance Analysis model (IPA) introduced by Martilla and James (1977) on 98 coaches and officials whom the athletes will share their view with. Generally, the success of the Shanghai Healthy Athlete program was revealed in this study. According to IPA, only the rating of importance (expectation) and experience (satisfaction) of effectiveness in crowd management fell behind the standard.
\end{abstract}

\section{摘 要}

根據2007國際特殊奧運會健康運動員計劃的報告, 7,289參賽運動員當中有4,879 $(66.9 \%$ )人參加了上海特奧的健康運動員計 劃。面對龐大的顧客群, 服務素質的管理的確是一個難題。很多專家都認同顧客滿意程度反映及影響服務素質之高低, 這現象也 是項目管理重要的一環。有見及此, 我們採用了顧客的期望及實際弳驗的差距計算法去(Importance-Performance Analysis model) 去評估客戶的感受及滿意程度。是次訪問的對象是 98 位教練及随隊教官, 因為他㑚無論在認知上及情感上都是動員的最佳伙伴, 再加上他們在健康理論方面及對事物的看法上較運動員成熟。整體而言, 教練及隨隊教官對上海特奧的健康運動員計劃無論在期 望及實際經驗都十分滿意，而美中不足的是其人群管理的措施稍迸於期望。

\section{Introduction}

Special Olympics is an international nonprofit making organization dedicated to empowering individuals with intellectual disabilities to become physically fit, productive and respected members of society through sports training and competition (Special Olympics, 2007). It currently serves 2.5 million people with intellectual disabilities in more than 200 programs in 165 countries (Lu, 2007). Special Olympics Healthy Athletes is a non sport program developed in 1996 (Lu, 2007) to help Special Olympics athletes improve their health and fitness, leading to enhanced sports experience and improved well-being" (Special Olympics, 2007). There are six items of testing program in the Healthy Athletes, which are Fit Feet, FUNfitness, Healthy Hearing, Health Promotion, Opening Eyes, MedFest and Special Smiles (Special Olympics, 2007). The Special Olympics Healthy Athletes expanded rapidly around the world. In 2005, there were more than 120 Special Olympics Programs provided Healthy Athletes screening (Lu, 2007). In 2006, 600 screening events took 
place and nearly 135,000 athletes received at least one screening. According to the Healthy Athlete Screening Report conducted by the International Special Olympics, there were 7289 athletes registered for the 2007 Shanghai Special Olympics World Summer Games and 4879 (66.9\%) of the total athletes participated the Healthy Athlete screening and the age range was between 5 to 69 (Special Olympics, 2007). With such a rapid growth in the numbers of athletes and events, to maintain and reinforce the management of those events should be emphasized, so that every athlete can enjoy the screenings. As the athletes are intellectually disabled, seldom will they raise the problem publicly, their coach and officials whom the athletes will share their view with should be interviewed. This study helps to address the concerns to the management party about the users' profiles of preference, the ways leading to customer satisfaction and the ways maintaining the customer satisfaction. Moreover, there were no researches about the management evaluation of the Healthy Athlete programs in Special Olympics, so there is a need to develop such a mechanism to serve 2.5 million people with intellectual disabilities in more than 165 countries.

As management research in Special Olympics is really scarce, the following concepts of management were enlisted to develop a systematic mechanism to maintain and to improve the programs of Special Olympics.

\section{Customer Satisfaction}

Many service organizations attribute their success on customer service (Manickas \& Shea, 1997). According to Lassar, Manolis and Winsor (2000), customer service quality which affected the customer satisfaction directly has been highly emphasized during the past decade and it is recognized as the critical measure of organizational performance. Kotler (2000) defined satisfaction as "a person's feelings of pleasure or disappointment resulting from comparing a product's perceived performance or outcome in relation to his or her expectations" (p.3).

Volunteers are not only the stakeholders but also the customers of the events. The satisfaction of volunteers directly affected the volunteers' loyalty and retention rate of the events (Lam \& Kam, 2009).

\section{Management Evaluation: Sociality and Customer Satisfaction}

Koermer, Ford, and Brant (2000) categorized socialites into two factors: courteous expressions (good manners, appreciative/ thankful manner) and personal connection (sales discussed your personal likes and dislikes, and discussed what you do for work). Communication is a medium of sociality which entailed both verbal and nonverbal behavior (e.g., smiling, direct eye contact) used to reduce psychological distance between individuals (Koermer, Ford, Toale \& Dohanos, 2003).As stated by Kandampully (1998), establishing personalized relationships with customers is crucial because "customers' perception of exceptional service is often associated with the personal interaction of the employees" ( p. 431). This concept coincided with the findings of Ford (2001) and Zeithaml, Berry and Parasuraman (1996) that most customers desired personalized relationships and communication with service providers. Service provider's interactions with customers could significantly influence the service organization's returning customer ratio (Kandampully, 1998). Sociality communication is therefore playing an important role in fostering customers' interpersonal loyalty to the provider (Koermer \& Linda, 2006).

\section{Management Evaluation: Quality of Employee}

According to the Procedure Guide of Employee Performance Evaluation of East Tennessee State University (2008), the quality of employee should include knowledge of work, quality of work, quality of interpersonal relationship, appearance and tidiness. Ford (2001) found that customers expected courtesies while receiving services from employee. Retail researchers have also found that customers' loyalty affected by the association of salesperson (Macintosh \& Lockshin, 1997). Communication skill is therefore an important factor which affected the revenue generation of a firm. Ammon, Southall and Blair (2004) showed us that all these skills were trainable. With proper and sufficient training, the effectiveness of employees would be upgraded.

\section{Management Evaluation: Crowded Management}

Nuttal (2001) expressed that the most hazardous time of a sport or entertainment event is the fan ingress and egress from the venue, but not the event itself. Crowded management has therefore been emphasized in the event management. Ammon, Southall and Blair (2004) defined 
that "crowded management is an organizational tool to assist facility and event administrators in providing a safety and enjoyable environment for their guests by implementing the facility/event policies and procedure" (p.145). Human resource including the facility manager and the staff is a key component of the crowded management. Facility manager needed to provide a safety and comfortable environment for the clients in order to eliminate the litigation. Ammon (1997) stated that an effective crowded management should involve trained and competent staff who can coordinate the event and facility, understand and comprehend facility risk management plans, assess crowd for potential problems, manage changing crowd behavior and demeanor, use good guest-service technique, respond to guest concerns, implement facility, event policies and procedures, assess potential problem guests and solve credential/ticketing, seating problem (p.151).

The condition of waiting area is also an important consideration of crowded management which will affect the customer satisfaction. (Ammon, Southall \& Blair, 2004). Tactics should include more standing rooms and creating more space in between sections to prevent overcrowding (Hiestand \& wood, 2001). Signage is another issue as they build a supportive network between sport facility management staff. Moreover, it helps customers know the directions and the information of the event, without signage, customer will get lost and the event will be ruined. Video Camera and surveillance system with high-resolution zoom lenses should be mounted in different stadiums in order to adjust and to allocate the resources effectively and efficiently (Ammon, Southall \& Blair, 2004).

\section{Management Evaluation: Volunteer Management}

"Volunteering is defined as the commitment of time and energy, for the benefit of the society and the community, the environment or individuals outside ones immediate family. It is undertaken freely and by choice, without concern for financial gain" (Volunteer Centre, 2008). Volunteer can boost the quality of the services in charities, organizations and congregations (The Urban Institute, 2004). Volunteers' management is not a one off job, but a continuous, successive development. A research conducted by the Urban Institute in USA (2004) showed that the percentage of time a paid staff volunteer coordinator devotes to volunteer management is positively related to the capacity of an organization to maintain and enlist volunteers.

\section{Importance Performance Analysis Model (IPA)}

The Importance-Performance Analysis (IPA) was first introduced by Martilla and James (1977) which was a useful tool measuring the understanding of the relationship between the customer judgment on the importance of the goods or services and the satisfaction when they experienced. It has been applied as an effective means of evaluating an organization's competitive position in the market, identifying improvement opportunities, and guiding strategic planning efforts (Hawes \& Rao, 1985; Myers, 1999). Hansen and Bush (1999) stated that IPA is a simple and effective technique that can facilitate organizations in identifying improvement priorities for service attributes and direct quality-based marketing strategies. Matzler, Bailom, Hinterhuber, Renzl and Pichler (2004) showed their consensus that firms can apply IPA to analyze two dimensions of service attributes: performance level (experience or satisfaction); and, importance to customers (expectation). "Analyses of these dimension attributes are then integrated into a matrix with four quadrants that helps a firm identify primary drivers of customer satisfaction and, based on these findings, set improvement priorities" (p. 67). In this matrix, attribute importance is depicted along the $\mathrm{x}$-axis and attribute performance (experience, satisfaction or service quality) is depicted along the y-axis. Four quadrant of the matrix involves the mean ratings from the customer's feedback and reflects the following meanings in 4-quadrant grids framework (Martilla \& James, 1977; Parasuraman, Berry \& Zeithaml, 1994; Matzler, Bailom, Hinterhuber, Renzl \& Pichler, 2004). Once the importance and performance of each attribute has been plotted, we divide the importance/performance map into quadrants (Bacon, 2003). The average importance (expectation) and the average performance (experience or satisfaction) is the one most frequently applied (Oliver, 1997; Bacon, 2003). This is also called the data-centered quadrant approach.

A. Concentrate Here - these variables have a high Importance and low Performance. It is a major weaknesses and requires immediate attention for improvement and.

B. Keep up the Good Work - these variables have a high Importance and high Performance. It is major strength and indicates opportunities for achieving or maintaining competitive advantage. 
C. Possible Overkill - these variables have a low Importance and high Performance This attribute is minor strength and indicates that business resources committed to these attributes would be overkill and should be deployed elsewhere.

D. Low Priority - these variables have a low Importance and high Performance. This attribute is a minor weaknesses and do not require additional effort.

Facing different situation, different tactics needed to be implemented. For example, major weaknesses should be put in the top priority and targeted for immediate improvement efforts (Martilla \& James, 1977). Conversely, attributes deemed major strengths should be maintained, leveraged, and heavily promoted (Lambert \& Sharma, 1990).

\section{Method}

Participants of this study refer to 98 coaches and officials of the athletes with intellectual disability. 50 (51\%) of participants were male while 48 (49\%) were female. $59(60.2 \%)$ of them were new comers of Healthy Athlete program, $23(23.5 \%)$ of them participated for 2 times, and $15(15.3 \%)$ of them participated more than three times.

The instrument is a 34 items questionnaire constructed in accordance to the model of ImportancePerformance Analysis (IPA) developed by Martilla and James (1977). The questionnaire was divided into two sections. The first section is to rate the participant's experience (satisfaction) while the second section is to rate the participant's importance (expectation) of Shanghai Athlete program. The questionnaire consists of five categories namely the site officials of the program, the environment of the program, the process of the program, the venue and the equipment of the program and the content of the program with 17 questions in the two sections respectively.

The five-point Likert Scale was adopted in this survey with 1 stands for the very unsatisfactory or very unimportant and 5 stands for very satisfactory or very important. Mean score of importance and performance were calculated for the 17 items of two sections of questionnaires. Gap scores were determined by subtracting the importance score from performance score to gain the level of service quality. A positive gap score indicated a good performance relative to the importance rating of the attribute. A negative gap score reflected that the performance rating was lower than the importance rating for the component. Later, the scores plotted onto a two-dimensional matrix, where arbitrary gridlines were established that reflected standards of service quality.

In order to test the relevancy, readability and communicability of the content of the instrument, a pilot study to test the instrument was conducted. An expert, a professor and a board member of Special Olympics of Hong Kong, was consulted to make sure the right questions were put in the right categories. The International Global Messenger of Special Olympics, Sam Tam, who is very familiar with the program, was invited to proof read the questionnaires to make sure the relevancy and communicability were right. 30 master students who studied Sport and Leisure Management were invited to complete the questionnaires and some ambiguous wordings of Chinese and English has been modified.

The period of data collection lasted for ten days (1st October, 2007 to $10^{\text {th }}$ October, 2007) during the 2007 Shanghai Special Olympics World Summer Games. 220 questionnaires were distributed and 108 questionnaires were collected. 10 questionnaires received were void due to failure of following the instructions and incompletion of data. Data were analyzed by Statistical Package of Social Science (SPSS) for Window 15.0 of. Descriptive statistics and Pearson Product Moment Correlation Coefficient, Oneway ANOVA and Pairwise Comparisons were computed. All statistical testing were performed with the level of significance at 0.05 .

\section{Results}

There were 17 items to be rated for importance (expectation) and the means were ranged in between 4.30 to 4.69 , which were in between of Important and Very Important. 17 items to be rated for experience (satisfaction) and the means were ranged in between 3.39 to 4.32, which were in between Neutral and Satisfactory.

The Pairwise Comparisons of the importance on different aspects of Shanghai Healthy Athlete program were examined in Table 1. The customers' rating on the importance of venue and equipment $(\mathrm{M}=4.57, \mathrm{p}<0.05)$ 
was significantly higher than the rating on the importance of environment $(\mathrm{M}=4.43, \mathrm{p}<0.05)$. The ratings of other categories were similar. With regards to experience, the Wilks' Lambda suggested that significant differences were presented $(\mathrm{F}=13.40, \mathrm{p}<0.05)$. There was a significant difference in rating of the 5 categories. According to the result of Pairwise Comparisons of the satisfaction in Table 2 , the customers' satisfaction on officials' performance $(\mathrm{M}=4.14)$ was significantly higher than the customers' satisfaction on environment $(\mathrm{M}=3.84)$ and customers' satisfaction on process $(\mathrm{M}=3.77)$. Customers' satisfaction on venue and equipment $(\mathrm{M}=4.13)$ was significantly higher than the customers' satisfaction on environment $(\mathrm{M}=3.84)$ and the customers' satisfaction on content $(\mathrm{M}=4.16)$ was also significantly higher than the customers' satisfaction on environment $(\mathrm{M}=3.84)$. In other words, the customer were more satisfied on the officials' performance, the venue and equipment of the program and the content of the program while they were more dissatisfied on the environment and the process of the program.

\section{Relationship between the Importance and the Experience}

To determine whether there is positive relationship between importance and experience, the Pearson productmoment correlation was examined. All the five categories of Experience of the Shanghai Healthy Athlete program were significant and positively correlated with the Importance of five categories of the Shanghai Healthy Athlete program. The five categories included the experience and importance of officials $(r=0.26, p<0.05)$, the experience and importance of environment $(\mathrm{r}=0.25$, $\mathrm{p}<0.05)$, the experience and importance of process $(\mathrm{r}=0.22$, $\mathrm{p}<0.05)$, the experience and importance of venue $(\mathrm{r}=0.30$, $\mathrm{p}<0.05)$, the experience and importance of content $(\mathrm{r}=0.28$, $\mathrm{p}<0.05$ ). In other words, the higher the expectations of the customers, the higher their satisfaction are.

Table 1. The Pairwise Comparison and Rating among the 5 categories in Importance.

\begin{tabular}{llll}
\hline (I) factor & (J) factor & Mean Difference $(\mathrm{I}-\mathrm{J})$ & Sig. $^{{ }^{a}}$ \\
\hline 1. Official & 2. Environment & .112 & .137 \\
& 3. Venue & .039 & 1.000 \\
& 4. Process & -.031 & 1.000 \\
& 5. Content & -.045 & 1.000 \\
2. Environment & 1. Official & -.112 & .137 \\
& 3. Venue & -.072 & 1.000 \\
& 4. Process & $-.143\left(^{*}\right)$ & .041 \\
3. Venue & 5. Content & -.156 & .095 \\
& 1. Official & -.039 & 1.000 \\
& 2. Environment & .072 & 1.000 \\
& 4. Process & -.071 & 1.000 \\
5. Content & -.084 & 1.000 \\
& 1. Official & .031 & 1.000 \\
& 2. Environment & $.143(*)$ & .041 \\
& 3. Venue & .071 & 1.000 \\
& 5. Content & -.014 & 1.000 \\
& 1. Official & .045 & 1.000 \\
& 2. Environment & .156 & .095 \\
& 3. Venue & .084 & 1.000 \\
4. Process & .014 & 1.000 \\
\hline
\end{tabular}

$* \mathrm{p}<.05$

Adjustment for multiple comparisons: Bonferroni. 
Table 2. The Pairwise Comparison and Rating among the 5 categories in Experience.

\begin{tabular}{|c|c|c|c|}
\hline (I) factor & (J) factor & Mean Difference (I-J) & Sig. ${ }^{a}$ \\
\hline \multirow[t]{4}{*}{ 1. Official } & 2. Environment & $.299(*)$ & .000 \\
\hline & 3. Venue & .014 & 1.000 \\
\hline & 4. Process & $.378(*)$ & .000 \\
\hline & 5. Content & -.015 & 1.000 \\
\hline \multirow[t]{4}{*}{ 2. Environment } & 1. Official & $-.299(*)$ & .000 \\
\hline & 3. Venue & $-.286(*)$ & .000 \\
\hline & 4. Process & .078 & 1.000 \\
\hline & 5. Content & $-.315(*)$ & .000 \\
\hline \multirow[t]{4}{*}{ 3. Venue } & 1. Official & -.014 & 1.000 \\
\hline & 2. Environment & $.286(*)$ & .000 \\
\hline & 4. Process & $.364(*)$ & .000 \\
\hline & 5. Content & -.029 & 1.000 \\
\hline \multirow[t]{4}{*}{ 4. Process } & 1. Official & $-.378(*)$ & .000 \\
\hline & 2. Environment & -.078 & 1.000 \\
\hline & 3. Venue & $-.364(*)$ & .000 \\
\hline & 5. Content & $-.393(*)$ & .000 \\
\hline \multirow[t]{4}{*}{ 5. Content } & 1. Official & .015 & 1.000 \\
\hline & 2. Environment & $.315(*)$ & .000 \\
\hline & 3. Venue & .029 & 1.000 \\
\hline & 4. Process & $.393(*)$ & .000 \\
\hline
\end{tabular}

$* \mathrm{p}<.05$

Adjustment for multiple comparisons: Bonferroni. 
The Gap Difference between the Mean Scores of Importance and Experience of Shanghai Healthy Athlete program

In Table 3, 17 components were sorted ascending according to the rating values of the mean scores. Participants' perception on the importance (expectation) of the Healthy Athlete program was all higher than their actual experiences (satisfaction) of Shanghai Healthy Athlete program. Though all the rating of experiences (satisfaction) were lined on the standard of "neutral" or "important", they were still lagged behind the perception on the importance (expectation)of the participants, in other words, improvements are needed.

Table 3. The Rank of Orders of the Gap Difference between the Mean Scores of Importance and Experience on 17 items of Shanghai Healthy Athlete Program.

\begin{tabular}{|c|c|c|c|c|}
\hline Code & Component & Importance & Experience & Gap \\
\hline $\mathrm{L}$ & $\begin{array}{l}\text { Effectiveness in crowded management (eg. little or no feeling of } \\
\text { over-crowdedness) }\end{array}$ & 4.53 & 3.39 & -1.14 \\
\hline I & Wait time between stations & 4.42 & 3.67 & -0.75 \\
\hline K & $\begin{array}{l}\text { Pre-program communication about the program (eg. clear } \\
\text { instructions about schedule and venue) }\end{array}$ & 4.48 & 3.74 & -0.74 \\
\hline $\mathrm{H}$ & $\begin{array}{l}\text { General appearance of the waiting area (eg. pleasant, comfortable } \\
\text { and spacious) }\end{array}$ & 4.37 & 3.68 & -0.69 \\
\hline Q & $\begin{array}{l}\text { Appropriateness of health check items (eg. it is what your athlete } \\
\text { needs) }\end{array}$ & 4.71 & 4.10 & -0.61 \\
\hline G & Clarity and adequacy of signage and instructions & 4.49 & 3.89 & -0.6 \\
\hline $\mathrm{D}$ & $\begin{array}{l}\text { Knowledge and skills related to the health station they are } \\
\text { responsible for (eg. ability to answer questions and give advice) }\end{array}$ & 4.62 & 4.10 & -0.52 \\
\hline $\mathrm{N}$ & Equipment (eg. In good condition, clean, sufficient in numbers) & 4.68 & 4.17 & -0.51 \\
\hline A & Promptness in attending to problems, queries, and issues & 4.48 & 3.98 & -0.5 \\
\hline $\mathrm{F}$ & General appearance of the environment (eg. pleasant and tidy) & 4.42 & 3.96 & -0.46 \\
\hline 0 & $\begin{array}{l}\text { Manpower (eg. sufficient manpower to attend to athletes, not too } \\
\text { many idling around) }\end{array}$ & 4.62 & 4.17 & -0.45 \\
\hline $\mathrm{C}$ & $\begin{array}{l}\text { Attitude towards the athlete's accompanying carers (eg. courteous, } \\
\text { encouraging, and friendly) }\end{array}$ & 4.58 & 4.19 & -0.39 \\
\hline B & Attitude towards athletes (eg. courteous, encouraging, and friendly) & 4.69 & 4.32 & -0.37 \\
\hline M & $\begin{array}{l}\text { Location of venue (eg. convenient to athletes, clear directions to } \\
\text { get there) }\end{array}$ & 4.40 & 4.04 & -0.36 \\
\hline $\mathrm{J}$ & Transportation to HA venue (eg. easy, well arranged, timely) & 4.56 & 4.26 & -0.3 \\
\hline $\mathrm{P}$ & Number of health check items (eg. sufficient variety) & 4.45 & 4.21 & -0.24 \\
\hline E & Professional look of the officials (eg. dress appearance) & 4.30 & 4.12 & -0.18 \\
\hline
\end{tabular}


The 4-quadrant Grid Framework of ImportancePerformance (experience) Analysis of Shanghai Healthy Athlete Program

In Figure 1, the difference between the reflections on the importance (expectation) and experience (satisfaction) of Shanghai Healthy Athlete program received had been plotted into a 4-quadrant grid to demonstrate where the directors and managers should pay attention to improve and enhance the customer satisfaction. This was a more specific and easy way to understand the action upon the right aspects. The intersection of the two axes of the 4-quadrant was set at the mean of all items of importance (expectation) of 4.52 and the means of all items of experience (satisfaction) of 4. The intersection might be adjusted by the managers' practical experience.

Figure 1. The 4-quadrant Grid Framework of Importance-Performance (experience) Analysis of Shanghai Healthy Athlete Program.

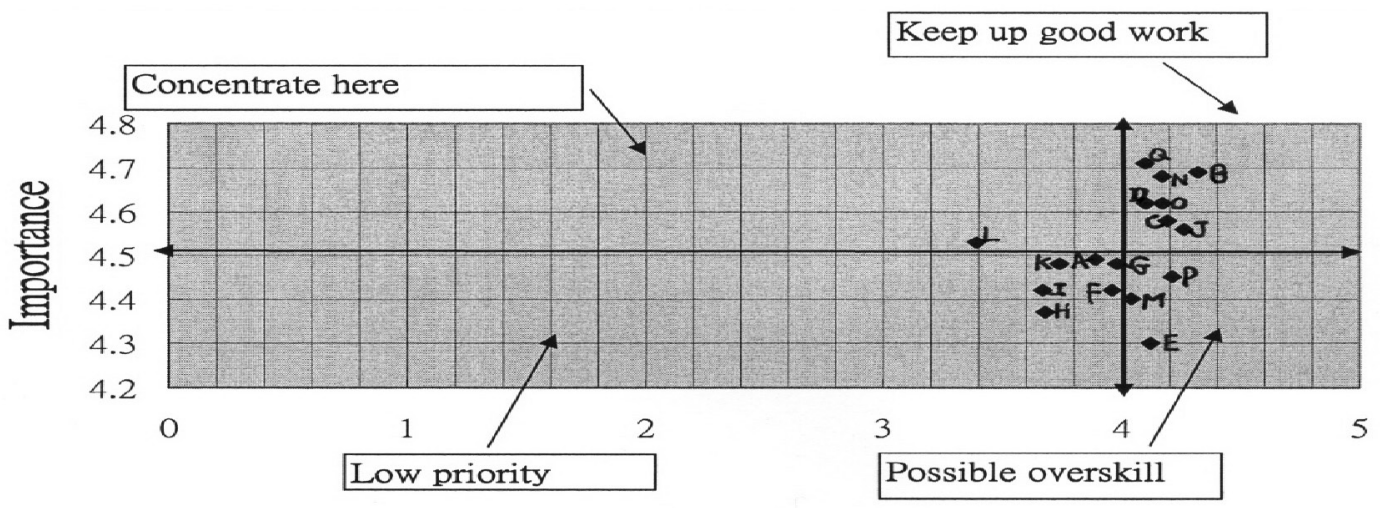

Experience

Notes:

I) Concentrate Here includes the following findings

L Effectiveness in crowded management (eg. little or no feeling of over-crowdedness)

2) Keep up the Good Work includes the following findings

Q Appropriateness of health check items (eg. it is what your athlete needs)

D Knowledge and skills related to the health station they are responsible for (eg. ability to answer questions and give advice)

$\mathrm{N}$ Equipment (eg. In good condition, clean, sufficient in numbers)

O Manpower (eg. sufficient manpower to attend to athletes, not too many idling around)

C Attitude towards the athlete's accompanying carers (eg. courteous, encouraging, and friendly)

B Attitude towards athletes (eg. courteous, encouraging, and friendly)

J Transportation to HA venue (eg. easy, well arranged, timely)

3) Possible Overkill includes the following findings

$\mathrm{G}$ Clarity and adequacy of signage and instructions

M Location of venue (eg. convenient to athletes, clear directions to get there)

$\mathrm{P}$ Number of health check items (eg. sufficient variety)

E Professional look of the officials (eg. dress appearance)

4) Low Priority includes the following findings

I Wait time between stations

$\mathrm{K}$ Pre-program communication about the program (eg. clear instructions about schedule and venue)

$\mathrm{H}$ General appearance of the waiting area (eg. pleasant, comfortable and spacious)

A Promptness in attending to problems, queries, and issues

F General appearance of the environment (eg. pleasant and tidy) 


\section{Discussion}

The difference between the Importance and Experience of 2007 Shanghai Healthy Athlete program had been plotted and illustrated in Figure 1.This analysis is more objective as the factors of expectations were compared to the actual feeling on pleasure or disappointment (Kotler, 2000). Generally, all the results generated by the IPA coincided with the findings of the Pairwise Comparisons of the importance (expectations) and performance (satisfaction) on different aspects of Shanghai Healthy Athlete program in Table 1and 2.

As the expectations and the satisfactions of participants on the Healthy Athlete program were very high, the intersection of the two axes of the 4-quadrant was set at the mean of all items of importance (expectation) of 4.52 and the means of all items of experience (satisfaction) of 4 .

In despite of the high requirement of expectation and satisfaction, there was only one item which fell in the criteria of Concentrate Here. The effectiveness in crowd management was the key weakness that the authority needed to rectify. As stated by Ammon, Southall and Blair (2004), the crowd management is not only the main tool to assist facility and administrators in providing a safety and enjoyable environment for the guests, but also an important tool to ensure the effectiveness of the a specific program, and it is therefore crucial for Healthy Athlete program. Here are few factors which caused to the ineffectiveness of the crowd management. Firstly, the tight competition schedule of different sports clashed as most of the competitions were arranged in the daytime right after the breakfast and lunch, so most of athletes rushed to the program when they were free or when their events were cancelled due to the raining. Secondly, the venue was too small for more than 10000 athletes, helpers, coaches, liaisons, parents and journalists. Thirdly there was only one narrow path which perforated from the entrance through different stations to the exit. The waiting area is another important factor which directly affects the crowd management (Ammon, Southall and Blair, 2004). The waiting area of 2007 Shanghai Special Olympics World Summer Games Healthy Athlete program was put nearby the exit at a dead ended corner, the athletes, helpers, coaches, liaisons and parents who didn't know English and Chinese simply stood in the middle of the path and chatted around in order to solve their problems. Fourthly, the instructions and the broadcasting were not enough to separate the athletes, so most of the athletes pileup in some stations. Fifthly, there was no mechanism to arrange the exceeded numbers of athletes to other non sports area like the Sports Experience program etc. and rearrange them back in a specific time.

On the other hand, there were four items fallen in the criterion of Possible Overkill because these experience (satisfaction) scores met or exceeded service quality standards, but a low level of importance (expectation) was assigned to this particular subject by the coaches and officials. In other words, some resources should be cut in these items in order to compensate the criteria of Concentrate Here where both importance (expectation) and experience (satisfaction) ratings fell behind the standard. The four items fallen in Possible Overkill are listed as follows

1. Clarity and adequacy of signage and instructions

2. Location of venue

3. Number of health check items

4. Professional look of the officials

For the Clarity and adequacy of signage and instructions, some resources should be cut as some of signage and instructions were obscured by the crowded as not all of them were placed at a high place. For the location of venue, though the venue for the sports competitions were very scattered, the transportation arranged by the organization to the non sports programs like Healthy Athlete program was very convenient. For the number of health check items, due to the tight competition schedule, most of the athletes who came to the program only for their own specific aims, for example, the athletes with ear difficulties would only go to the ear checking station and ask for the referral of the doctors to their own community, and seldom would they go to all other programs, the other programs were therefore not that important for them. Some resources like over-promotion of the specific programs should therefore be cut as athletes came with their own needs in a limited period of time. Resources like the signage, instructions, capital resources and the human resources should be put in the component of crowd management which fell in the criteria of Concentrate Here. 
Furthermore, there were seven components fallen into the Keep up the Good Work grid. Such Importance (expectation) and Experience (satisfaction) ratings met or exceeded serviced quality standards. The seven components fallen in Keep up the Good Work are listed as follows

1. Appropriateness of health check items (eg. it is what your athlete needs)

2. Knowledge and skills related to the health station they are responsible for (eg. ability to answer questions and give advice)

3. Equipment (eg. In good condition, clean, sufficient in numbers)

4. Manpower (eg. sufficient manpower to attend to athletes, not too many idling around)

5. Attitude towards the athlete's accompanying carers (eg. courteous, encouraging, and friendly)

6. Attitude towards athletes (eg. courteous, encouraging, and friendly)

7. Transportation to HA venue (eg. easy, well arranged, timely)

These are the major strength and indicate opportunities for achieving or maintaining competitive advantage (Bacon, 2003). This is the pride of the managerial teams of the 2007 Shanghai Healthy Athlete program, as the expectations and the satisfactions of participants on the Healthy Athlete program were very high, the intersection of the two axes of the 4-quadrant was set at the mean of all items of importance (expectation) of 4.52 and the means of all items of experience (satisfaction) of 4. Keeping up the good works is therefore important to maintain the competitive advantage (Bacon, 2003).

Lastly, there were five items found in the Low Priority grid. Experience (satisfaction) scores did not meet the service quality standards, but respondents did not place a high level of importance (expectation) on these service. The five items fallen in Low Priority are listed as follows

1. Wait time between stations

2. Pre-program communication about the program (eg. clear instructions about schedule and venue)

3. General appearance of the waiting area (eg. pleasant, comfortable and spacious)

4. Promptness in attending to problems, queries, and issues

5. General appearance of the environment (eg. pleasant and tidy)
Actually, this is another area that the organization needs to focus on. Although, Martilla and James (1977) showed that this attribute is a minor weaknesses and do not require additional effort, small extent of resources should be retracted from the criterion of Possible Overkill to some of the items located in the criterion of Low Priority. Due to the high expectations of our participants, the mean of importance (expectation) is 4.52, which is higher than the middle point of "important" and "very important". With extremely high expectations, lots of items of management fallen into the criterion of Low Priority. Though the items of Wait time between stations, Pre-program communication about the program and the General appearance of the waiting area were located in the criterion of Low Priority, their Gap Score between the importance (expectation) and the experience (satisfaction) were ranked in the second place (Waiting time between station, Gap Score=-0.75), third place (Pre-program communication about the program, Gap Score=-0.74) and fourth place (General appearance of the waiting area, Gap Score=-0.69). In other words, participants' expectations on these items were not high, but they were very unsatisfied on these managerial arrangements. For the item of the Promptness in attending to problems, queries, and issues and the item of General appearance of the environment, though the participants were not satisfied on these items by their experiences, they might not treat it as a serious problem.

\section{Conclusion}

Generally, the program was successful as both of the expectations and satisfactions were high, however the satisfaction of effectiveness of crowd management fell behind the expectation and some resources should be cut in some components in order to maximize the effectiveness of the program. Managerial rectifications are therefore needed to polish the next Healthy Athlete program, so that the benefits of people with intellectual disability will be fully realized.

Moreover, there were little researches about the management evaluation of the Special Olympics which serves more than 2.5 million people with intellectual disabilities in more than 165 countries. To develop a systematic mechanism to maintain and to improve the life of people with intellectual disability and the programs of Special Olympics is therefore needed. 


\section{References}

Ammon, R. Jr. (1997). An executive's guide to crowded management issues. Paper presented at the International association of Assembly Managers $72^{\text {nd }}$ Annual Conference and Trade Show, Dallas, TX.

Ammon, R.Jr., Southall, R.M., \& Blair, D.A. (2004). Sport facility management: Organizing events and mitigating risks. Morgantown: Sheridian Books.

Bacon, D.R. (2003). A comparison of approaches to importance-performance analysis. International Journal of Market Research, 45(1), 55-71.

East Tennessee State University. (2008). Employee performance evaluation: Procedures guide. Retrieved February 1, 2008, from http://www.etsu.edu/humanres/ guide.htm

Ford, W. (2001). Customer expectations for interactions with service providers: Relationship versus encounter orientation and personalized service communication. Journal of Applied Communication Research, 29(1), 1- 29.

Hansen, E., \& Bush, R. J. (1999). Understanding customer quality requirements: model and application. Industrial Marketing Management, 28(2), 119-130.

Hawes, J. M., \& Rao, C. P. (1985). Using importanceperformance analysis to develop health care marketing strategies. Journal of Health Care Marketing, 5, $19-25$.

Hiestand, M., \& Wood, S. (2001). Fan conduct rises on NFL agenda: Some see violence at recent games as precursor to soccer-style hooliganism. USA Today, P.3C.

Kandampully, J. (1998). Service quality to service loyalty: A relationship which goes beyond customer services. Total Quality Management, 9(6), 431-443.

Koermer, C., Ford, W., \& Brant, C. (2000). Toward the development of a service provider sociality scale and its relationship to customer satisfaction and loyalty. Communication Research Reports, 17(3), 250-259.
Koermer, C., Ford, W., Toale, M., \& Dohanos, A. (2003). Confirmatory analysis of the factorial structure and validity of the service provider sociality scale. Communication Research Reports, 20(2), 124-133.

Koermer, C.D., \& Linda, L.M. (2006). Sociality communication: Its influence on customer loyalty with the service provider and service organization. Communication Quarterly. 54(1), 53-65

Kotler, P. (2000). Marketing management: The millennium edition. Prentice Hall International, Inc.

Lambert, D. M., \& Sharma, A. (1990). A customerbased competitive analysis for logistics decisions. International Journal of Physical Distribution \& Logistics Management, 20(1), 17-24.

Lam, M. H. S., \& Kam, Leslie S. (2009). Management Evaluation of the 2008 Paralympics Equestrian Games in Hong Kong: The View of Volunteers. Hong Kong Recreation Review, 21, 46-54.

Lassar, W.M., Mannolis, C., \& Winsor, R.D. (2000). Service quality perspectives and satisfaction in private banking. Journal of Consumer Affairs, 32(2), 227251.

Lu, Y. (2007). Special Olympics movement. Sheng Yang: Liao Ning Jiaoyu Chuban She.

Macintosh, G., \& Lockshin, L. (1997). Retail relationships and store loyalty: A multi-level perspective. International Journal of Research in Marketing, 5, 487-497.

Manickas, P.A., \& Shea, L.J. (1997). Hotel complaint behavior and resolution: A content analysis. Journal of Travel research, 36, 68-73.

Martilla, J.A.,\& James, J.C. (1977). Importance-performance analysis. Journal of Marketing, 41(1), 77-99.

Matzler, K., Bailom, F., Hinterhuber, H. H., Renzl, B., \& Pichler, J. (2004). The asymmetric relationship between attribute-level performance and overall customer satisfaction: a reconsideration of the importance-performance analysis. Industrial Marketing Management, 33(4), 271-277. 
Myers, J. (1999). Measuring customer satisfaction: Hot buttons and other measurement issues. Chicago: American Marketing Association.

Nutall, I. (2001). Secure all areas. Stadia, 10, 83-84.

Oliver, R.L. (1997). Satisfaction. Boston, MA: McGrawHill.

Parasuraman, A., Berry, L.L., \& Zeithaml, V. (1994). Reassessment of expectations as a comparison standard in measuring service quality: Implications for further research. Journal of Marketing, 58, 111-124.

Special Olympics. (2007) Retrieved October 20, 2008, from http://www.specialolympics.org/ Special+Olympics+Public+Website/English/About_Us/ Mission_Vision/default.htm

The Urban Institute. (2004) Volunteer Management Capacity in America's Charities and Congregations: A Briefing Report. Washington D.C.
Volunteer Centre. (2008) What is volunteering. Retrieved December 5, 2008, from http://www. volunteersouthdublin.ie/volunteers/articles-forvolunteers/2-what-is-volunteering

Youth Daily. (2007) Retrieved October 20, 2008, from http://www.why.com.cn Zeithaml, V., Berry, L., \& Parasuraman, A. (1996). The behavioral consequences of service quality. Journal of Marketing, 60, 31-46.

Zeithaml, V., Berry, L., \& Parasuraman, A. (1996). The behavioral consequences of service quality. Journal of Marketing, 60, 31-46.

\section{Correspondence:}

Author: Michael, H.S. Lam

Address: 13/F., 8 On Muk Street, Shek Mun, Shatin, Hong Kong Phone: (852) 34113108

Fax: (852) 34113356 